\title{
Evaluating the efficiency of functioning of integrated structures in industry
}

\author{
Larisa Suvorova ${ }^{1, *}$, Tatyana Baibakova $^{1}$, and Irina Pestova ${ }^{1}$ \\ ${ }^{1}$ Economics Department, Vyatka State University, 610000 Kirov, Russia
}

\begin{abstract}
In the article the authors review approaches to evaluating the efficiency of the integrated structures in industry in order to improve the methodology of this evaluation. In contrast to existing indicators for evaluating the efficiency, which characterize the performance of some aspects of the integrated structures activities, the authors propose the methodology based on calculating and comparing general and individual efficiency indicators of current (operating), financial and investing activities on the integrated structure as a whole. These indicators are presented in the form of the coefficients. By means of mathematical analysis, the authors have found out the strong and direct correlation among the given indicators, which confirms the objectivity of choosing the indicators. The received results of evaluating the efficiency of functioning of the integrated structures are proposed for use in the developed algorithm of making managerial decisions. The validity of the developed methodology is shown on the example of the integrated structure of the joint-stock company "Kirov Dairy Plant".
\end{abstract}

Keywords: integrated structures, methods of evaluation, industry, efficiency of functioning

\section{Introduction}

In the field of economics, the organizational manifestation of the integration is forming the integrated structures. It is made with the help of integrating resources and capital in order to build the integrity of the production and technological, financial and economic chains in the company activities $[1,2]$.

The integrated structure is viewed as the union of industrial enterprises and companies on the basis of the technological principle in order to improve the quality parameters of the finished product, to optimize its production and marketing costs, to develop mutually beneficial economic relations, to consolidate individual functional structures [3]. The purpose of merging enterprises and companies into the integrated structure is to strengthen its competitive potential, to increase output through applying innovative technologies and increasing the competitiveness of their products.

One of the most important tasks of researching the activities of the integrated structure is to evaluate the efficiency of its functioning.

Nowadays there are three groups of methods for evaluating the efficiency of company functioning.

The first group of methods is based on using the quantitative approach, which allows to evaluate the cost indicators of the company's performance and their dynamics [2, 4].
Using the methods of the second group gives the possibility to make the calculation of indicators of quality of production, the level of qualification of the personnel, the level of technology and of diversification of production [5].

The methods of the third group rely on using the integrated approach, which helps us to evaluate the efficiency indicators of companies functioning $[6,7,8,9]$.

In spite of the existing extensive system of indicators used to evaluate and analyze the effectiveness of the company's activities, there is a need to develop the methodology for evaluating the efficiency of the integrated structure as the whole entity.

\section{Defining the task of the research}

Today there is a large number of publications concerning the evaluating the efficiency of functioning of the integrated structures $[3,5,6,10-17]$. The analysis of scientific literature led us to the conclusion that evaluating the efficiency of functioning of the integrated structures is carried out with the use of quantitative, qualitative and complex approaches. The disadvantage of the existing approaches is that there are no causal relationships between the used efficiency indicators in the existing methods of calculation, which does not

*Corresponding author: larsuvorova@mail.ru 
result in obtaining the fair evaluation of the efficiency of the integrated structure as a whole.

The aim of this study is to develop the methodology, based on calculating and comparing general and individual indicators of current (operating), financial and investing activities of the integrated structure as an economic system.

\section{Developing the approaches to evaluating the efficiency of functioning of integrated structures}

Modern scientists` approaches to evaluating the efficiency of functioning of the integrated structures are very diverse and they allow to determine the performance of their activities according to a number of positions. Let us consider some of the main approaches to evaluating the efficiency of functioning of the integrated structures (Table 1).

Table 1. Approaches to evaluating the efficiency of functioning of integrated structures [1].

\begin{tabular}{|c|c|}
\hline $\begin{array}{l}\text { The Name } \\
\text { of the } \\
\text { Approach }\end{array}$ & The Essence of the Approach \\
\hline $\begin{array}{l}\text { The } \\
\text { principle of } \\
\text { "Triple } \\
\text { Helix" }\end{array}$ & $\begin{array}{c}\text { The performance of the integrated structures is } \\
\text { evaluated according to the performance of its } \\
\text { three components: science, business, } \\
\text { government }\end{array}$ \\
\hline $\begin{array}{l}\text { Contextual } \\
\text { approach }\end{array}$ & $\begin{array}{l}\text { The integrated structure has the contextual } \\
\text { characteristic of useful results that can be } \\
\text { obtained from the system, the evaluation of } \\
\text { which shows the efficiency of its functioning }\end{array}$ \\
\hline $\begin{array}{l}\text { Program and } \\
\text { target- } \\
\text { oriented } \\
\text { approach }\end{array}$ & $\begin{array}{l}\text { The efficiency of functioning of the integrated } \\
\text { structures is determined on the basis of } \\
\text { evaluating the degree of target achievement. In } \\
\text { this case, the evaluation is the ratio of the level } \\
\text { of the target implementation with the costs for } \\
\text { its achievement }\end{array}$ \\
\hline $\begin{array}{l}\text { Managerial } \\
\text { approach }\end{array}$ & $\begin{array}{c}\text { The efficiency of functioning of the integrated } \\
\text { structures is determined at different levels of } \\
\text { government: state, industries, region and } \\
\text { enterprises }\end{array}$ \\
\hline $\begin{array}{l}\text { Synergetic } \\
\text { approach }\end{array}$ & $\begin{array}{l}\text { Evaluating the performance of the integrated } \\
\text { structures is made on the basis of calculating } \\
\text { the net synergetic effect }\end{array}$ \\
\hline $\begin{array}{l}\text { Structural } \\
\text { approach }\end{array}$ & $\begin{array}{l}\text { Evaluating the performance of the integrated } \\
\text { structures can be carried out on the basis of the } \\
\text { structural shift method, which relies on the } \\
\text { assumption that the effectiveness is determined } \\
\text { by the combined efforts of three factors: the } \\
\text { growth of the national economy, the growth of } \\
\text { an industry in the country, the growth of the } \\
\text { regional economy }\end{array}$ \\
\hline $\begin{array}{l}\text { Economic } \\
\text { approach }\end{array}$ & $\begin{array}{l}\text { Applying different methods of functioning } \\
\text { evaluation of the integrated structures, } \\
\text { including income, market and costs methods }\end{array}$ \\
\hline
\end{tabular}

\begin{tabular}{|c|c|}
\hline $\begin{array}{c}\text { Aggregative } \\
\text { approach }\end{array}$ & $\begin{array}{c}\text { Making up the integral indicators of } \\
\text { functioning evaluating of the integrated } \\
\text { structures on the basis of its main } \\
\text { characteristics, parameters, features and } \\
\text { properties: competitiveness, exports, } \\
\text { employment, innovation, manufacturing, } \\
\text { relationship of participants, science and } \\
\text { education, investments, gross value added, } \\
\text { area, productivity }\end{array}$ \\
\hline $\begin{array}{c}\text { Adapting } \\
\text { the idea of } \\
\text { cross- } \\
\text { efficiency }\end{array}$ & $\begin{array}{c}\text { The approach allows to connect different levels } \\
\text { of the integrated structures. A level is a } \\
\text { standard, and the level of an individual item } \\
\text { cannot be higher than the level of the cluster as } \\
\text { a system }\end{array}$ \\
\hline $\begin{array}{c}\text { Adaptive } \\
\text { approach }\end{array}$ & $\begin{array}{c}\text { Adapting the idea of a dynamic normal and the } \\
\text { order of indicators to evaluating the efficiency } \\
\text { of functioning of the integrated structures }\end{array}$ \\
\hline
\end{tabular}

For evaluating the efficiency of functioning of the integrated structures one can use different groups of indicators (Table 2).

Table 2. Groups of indicators for evaluating the efficiency of functioning of the integrated structures.

\begin{tabular}{|c|c|c|}
\hline $\begin{array}{l}\text { Group of } \\
\text { Indicators }\end{array}$ & Indicators & Authors \\
\hline $\begin{array}{l}\text { The main } \\
\text { indicators of } \\
\text { functioning }\end{array}$ & $\begin{array}{c}\text { The increase in volume of } \\
\text { output. } \\
\text { The increase in profit } \\
\text { growth. } \\
\text { Improving parameters of } \\
\text { product quality. } \\
\text { The increase in labour } \\
\text { productivity. } \\
\text { The increase in } \\
\text { productivity from the use } \\
\text { of labor and capital } \\
\text { investments. } \\
\text { The decrease in costs in the } \\
\text { production process. }\end{array}$ & $\begin{array}{l}\text { Gordeev } \\
\text { A. V. } \\
\text { Donskova } \\
\text { S. V. [2] }\end{array}$ \\
\hline $\begin{array}{l}\text { Indicators } \\
\text { summarizing } \\
\text { the results of } \\
\text { economic } \\
\text { activity }\end{array}$ & $\begin{array}{l}\text { Indicative industry profits. } \\
\text { Indicative profitability. } \\
\text { Indicative expenditures for } \\
\text { a unit of output. }\end{array}$ & $\begin{array}{c}\text { Kosholkina } \\
\text { L., } \\
\text { Borhunov } \\
\text { N., } \\
\text { Rodionova } \\
\text { O. A. [4] }\end{array}$ \\
\hline $\begin{array}{l}\text { Indicators of the } \\
\text { financial aspect } \\
\text { of activities }\end{array}$ & $\begin{array}{l}\text { The increase in the value } \\
\text { of the enterprise. } \\
\text { The decrease in transaction } \\
\text { costs. } \\
\text { Savings on tax payments. } \\
\text { The decrease in overheads. }\end{array}$ & \multirow[t]{2}{*}{$\begin{array}{c}\text { Shmidt } \\
\text { U. D., } \\
\text { Romanova } \\
\text { I. M., } \\
\text { Mihina I. S. } \\
\text { [5] }\end{array}$} \\
\hline $\begin{array}{l}\text { Indicators of the } \\
\text { production } \\
\text { aspect of } \\
\text { activities }\end{array}$ & $\begin{array}{c}\text { Reduced costs of } \\
\text { productive work. } \\
\text { Improved product quality. } \\
\text { The expansion of product } \\
\text { range. } \\
\text { The growth of returns from } \\
\text { the use of means and } \\
\text { objects of labour. }\end{array}$ & \\
\hline
\end{tabular}




\begin{tabular}{|c|c|c|}
\hline $\begin{array}{l}\text { Indicators of the } \\
\text { investment } \\
\text { aspect of } \\
\text { activities }\end{array}$ & $\begin{array}{l}\text { The increased investments } \\
\text { in long-range assets. } \\
\text { The increased investments } \\
\text { in the development of new } \\
\text { technologies in the } \\
\text { production of traditional } \\
\text { and new products. } \\
\text { The increased investments } \\
\text { in production equipment. }\end{array}$ & \\
\hline $\begin{array}{l}\text { Indicators of } \\
\text { evaluating the } \\
\text { integrated } \\
\text { organization } \\
\text { potential }\end{array}$ & $\begin{array}{l}\text { Evaluating the peculiarity } \\
\text { of funds. } \\
\text { Evaluating the market } \\
\text { concentration. } \\
\text { Evaluating the growth } \\
\text { potential of the market } \\
\text { power. } \\
\text { Evaluating the effect of } \\
\text { logistics decisions in the } \\
\text { field of supplies. }\end{array}$ & \multirow[t]{3}{*}{$\begin{array}{l}\text { Sitnikova } \\
\text { T. V. [6] }\end{array}$} \\
\hline $\begin{array}{l}\text { Indicators for } \\
\text { selecting } \\
\text { potential } \\
\text { organizations in } \\
\text { order to build } \\
\text { the integrated } \\
\text { organization } \\
\text { and their } \\
\text { evaluation }\end{array}$ & $\begin{array}{l}\text { Evaluating the potential of } \\
\text { strength and sustainability } \\
\text { of the cooperative. } \\
\text { Evaluating the market } \\
\text { potential. } \\
\text { Evaluating the effect of } \\
\text { logistics decisions. } \\
\text { Evaluating the merger of } \\
\text { other organizations into the } \\
\text { integrated structure. }\end{array}$ & \\
\hline $\begin{array}{l}\text { Indicators for } \\
\text { monitoring the } \\
\text { integrated } \\
\text { company }\end{array}$ & $\begin{array}{l}\text { Excluding the } \\
\text { organizations, that have } \\
\text { exhausted resource } \\
\text { efficiency, from the } \\
\text { structure. } \\
\text { The formation of new } \\
\text { integration connections } \\
\text { among the entered } \\
\text { organizations or the } \\
\text { inclusion of new } \\
\text { companies. }\end{array}$ & \\
\hline $\begin{array}{l}\text { Individual } \\
\text { indicators }\end{array}$ & $\begin{array}{l}\text { As for federal and state } \\
\text { organizations it is the } \\
\text { proceeds from selling the } \\
\text { products of the companies } \\
\text { that are members of the } \\
\text { holding. } \\
\text { As for regional and } \\
\text { municipal organizations it } \\
\text { is the number of } \\
\text { employees. }\end{array}$ & \multirow[t]{3}{*}{$\begin{array}{l}\text { Shubin } \\
\text { S. A. [7] }\end{array}$} \\
\hline $\begin{array}{l}\text { Indicators of the } \\
\text { efficiency of } \\
\text { using raw } \\
\text { materials }\end{array}$ & $\begin{array}{l}\text { The level of food } \\
\text { consumption by } \\
\text { population. } \\
\text { The size of the gross } \\
\text { product. } \\
\text { The yield of marketable } \\
\text { products. } \\
\text { Gross income. } \\
\text { Net profit. }\end{array}$ & \\
\hline $\begin{array}{l}\text { Indicators } \\
\text { revealing the } \\
\text { degree of }\end{array}$ & $\begin{array}{l}\text { The availability of raw } \\
\text { materials for the } \\
\text { Production Capability. }\end{array}$ & \\
\hline
\end{tabular}

\begin{tabular}{|c|c|c|}
\hline integration & $\begin{array}{c}\text { The distance of } \\
\text { transporting raw materials }\end{array}$ & \\
\hline
\end{tabular}

A large number of existing indicators allow to make diverse evaluation of activities of companies that are members of the integrated structure [8-17], but there are no indicators to measure the efficiency of functioning of the integrated structure as a whole.

\section{Developing the methodology of evaluating the efficiency of functioning of integrated structures in industry}

Multidimensional nature of integrated structures activities requires using a certain number of characteristics in the form of appropriate efficiency indicators while evaluating the efficiency of the integrated structures. The appropriate efficiency indicators form the system, which gives them unity in their mutual relations.

The authors propose the methodology for evaluating the efficiency of the integrated structures [18-22]. This methodology consists of three stages and it is based on calculating and comparing general and individual efficiency indicators of current (operating), financial and investing activities (Fig. 1).

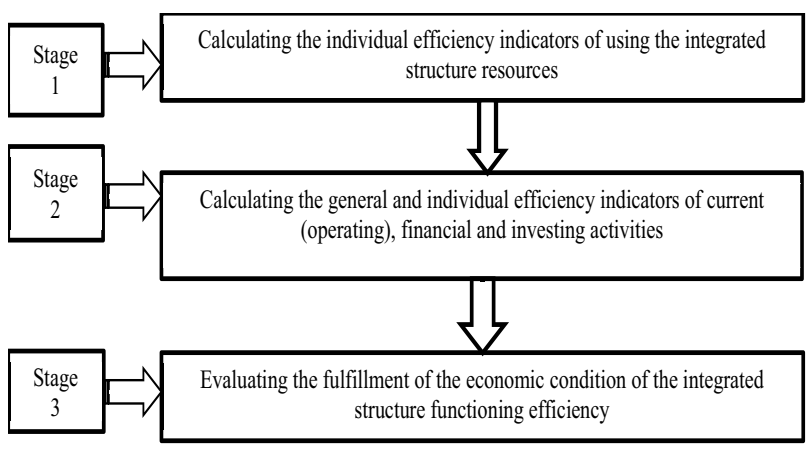

Fig. 1. Stages of evaluating the efficiency of functioning of the integrated structure in industry.

General and individual indicators for evaluating the efficiency of functioning of the integrated structures are presented in the form of dimensionless coefficients (Table 3).

The correlation coefficients were calculated by means of the program Excel using the "Data Analysis" package. These coefficients let us make the conclusion that there is a strong direct correlation among figures presented in Table 3.

After calculating the general indicators $\left(\mathrm{E}_{\mathrm{ca}}, \mathrm{E}_{\mathrm{fa}}\right.$ and $\left.E_{i a}\right)$ we matched their values in order to make future managerial decisions. The logical arrangement of the general indicators of the efficiency of functioning is determined by the technological expediency of functioning of the integrated structure. 
Table 3. General and individual indicators for evaluating the efficiency of functioning of the integrated structures in industry.

\begin{tabular}{|c|c|c|c|}
\hline \multirow[t]{2}{*}{$\begin{array}{l}\text { A type of } \\
\text { activity }\end{array}$} & \multirow{2}{*}{$\begin{array}{l}\text { Individual } \\
\text { indicators of } \\
\text { the efficiency } \\
\text { of using } \\
\text { resources }\end{array}$} & \multicolumn{2}{|c|}{$\begin{array}{l}\text { General indicators of the } \\
\text { efficiency of functioning }\end{array}$} \\
\hline & & $\begin{array}{l}\text { Calculation } \\
\text { formulas }\end{array}$ & $\begin{array}{l}\text { Correlation } \\
\text { coefficient }\end{array}$ \\
\hline $\begin{array}{c}\text { Current } \\
\text { (operating) } \\
\text { activity }\end{array}$ & $\begin{array}{c}\mathrm{R}_{\mathrm{f}}-\text { fixed assets } \\
\text { turnover ratio; } \\
\mathrm{R}_{\mathrm{t}}-\text { circulating } \\
\text { assets turnover } \\
\text { ratio, turnover } \\
\text { per year }\end{array}$ & $\begin{array}{c}\mathrm{E}_{\mathrm{ca}}=\mathrm{R}_{\mathrm{f}} \times \mathrm{R}_{\mathrm{t}} \\
\mathrm{E}_{\mathrm{ca}}-\text { efficiency } \\
\text { ratio of current } \\
\text { (operating) } \\
\text { activity }\end{array}$ & 0.94 \\
\hline $\begin{array}{c}\text { Financial } \\
\text { activity }\end{array}$ & $\begin{array}{c}\mathrm{R}_{\mathrm{d}}-\text { debt ratio; } \\
\mathrm{P}_{\mathrm{bc}}- \\
\text { profitability of } \\
\text { borrowed } \\
\text { capital, } \\
\text { coefficient }\end{array}$ & $\begin{array}{c}\mathrm{E}_{\mathrm{fa}}=\mathrm{R}_{\mathrm{d}} \times \mathrm{P}_{\mathrm{bc}} \\
\mathrm{E}_{\mathrm{fa}}-\text { efficiency } \\
\text { ratio of financial } \\
\text { activity }\end{array}$ & 0.63 \\
\hline $\begin{array}{l}\text { Investing } \\
\text { activity }\end{array}$ & $\begin{array}{c}\mathrm{C}_{\mathrm{c}}-\text { capital } \\
\text { coefficient; } \\
\mathrm{R}_{\mathrm{c}}-\text { circulating } \\
\text { assets capacity } \\
\text { ratio; } \\
\mathrm{I}_{\mathrm{c}}-\text { capital } \\
\text { intensity }\end{array}$ & $\begin{array}{c}\mathrm{E}_{\mathrm{ia}}=\mathrm{C}_{\mathrm{c}} \times \mathrm{R}_{\mathrm{c}} \times \mathrm{I}_{\mathrm{c}} \\
\mathrm{E}_{\mathrm{ia}}-\text { efficiency } \\
\text { ratio of financial } \\
\text { activity }\end{array}$ & 0.94 \\
\hline
\end{tabular}

The developed algorithm of decision-making supposes the choice of actions according to the results of comparing the proposed efficiency indicators of the current (operating), financial and investing activities (Fig. 2).

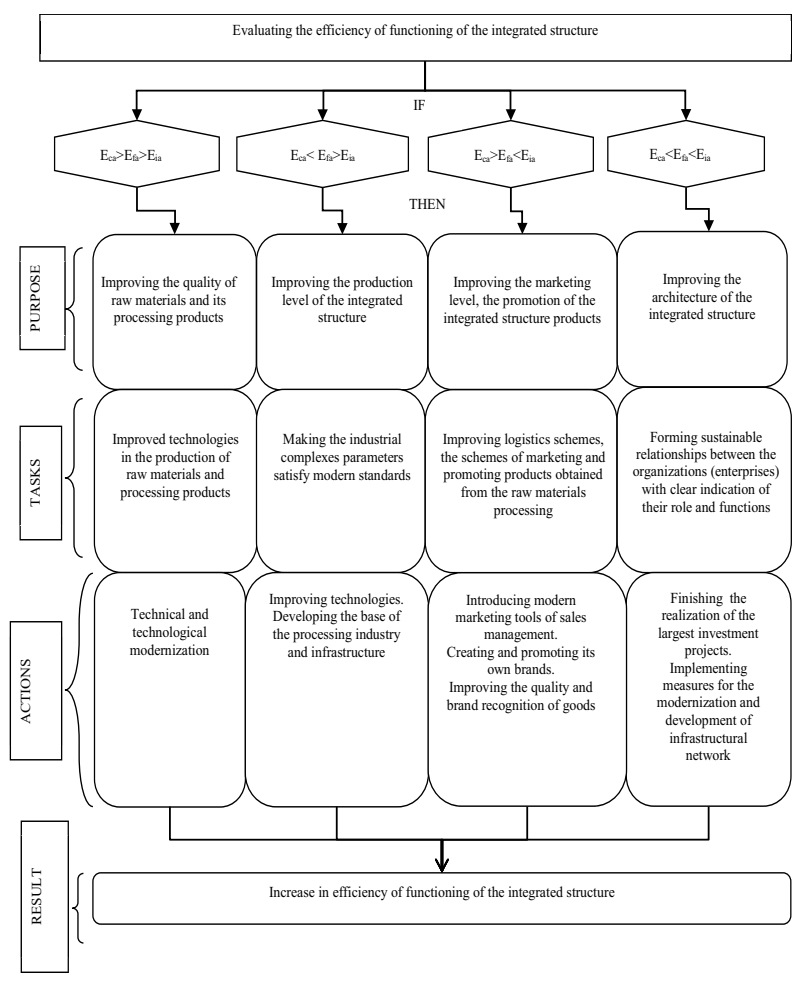

Fig. 2. The algorithm of making managerial decisions of the integrated structure in industry.
Under the condition when $\mathrm{E}_{\mathrm{ca}}>\mathrm{E}_{\mathrm{fa}}>\mathrm{E}_{\mathrm{ia}}$, the integrated structure has the task to improve production technologies through its modernization.

Receiving the condition when $\mathrm{E}_{\mathrm{ca}}<\mathrm{E}_{\mathrm{fa}}>\mathrm{E}_{\mathrm{ia}}$, the integrated structure needs to aim at developing the material-technical base and its infrastructure. It should be done in order to make economic security parameters of industrial complexes satisfy modern standards.

Under the condition when $\mathrm{E}_{\mathrm{ca}}>\mathrm{E}_{\mathrm{fa}}<\mathrm{E}_{\mathrm{ia}}$, the integrated structure needs to improve its logistics schemes of promoting finished products, to create and promote its own brands, to raise its brand name recognition.

In the case of the condition when $\mathrm{E}_{\mathrm{ca}}<\mathrm{E}_{\mathrm{fa}}<\mathrm{E}_{\mathrm{ia}}$, the integrated structure needs to focus on forming sustainable relationships between its constituent organizations with clear indication of their role and functions. This is solved through realizing major investment projects, implementing measures for modernization and development of the infrastructure network.

\section{The practical importance of the research}

The proposed methodology was tested on the data about functioning of the integrated structure of the joint-stock company (JSC) "Kirov Dairy Plant", which is the leader of raw milk processing in the Kirov region nowadays.

According to the results of the evaluation it is found out that the condition of the functioning efficiency of the integrated structure of the JSC "Kirov Dairy Plant" has not been fulfilled (Table 4).

Table 4. Indicators of the efficiency of functioning of the JSC "Kirov Dairy Plant" before and after the integration.

\begin{tabular}{|c|c|c|c|}
\hline $\begin{array}{l}\text { A group of } \\
\text { indicators }\end{array}$ & $\begin{array}{l}\text { The name of an } \\
\text { indicator }\end{array}$ & $\begin{array}{c}\text { Before } \\
\text { integration }\end{array}$ & $\begin{array}{c}\text { After } \\
\text { integration }\end{array}$ \\
\hline \multirow{7}{*}{$\begin{array}{l}\text { Individual } \\
\text { indicators } \\
\text { of the } \\
\text { efficiency } \\
\text { of using } \\
\text { resources }\end{array}$} & $\begin{array}{l}\text { Fixed assets } \\
\text { turnover ratio }\end{array}$ & 1.28 & 1.87 \\
\hline & $\begin{array}{l}\text { Circulating } \\
\text { assets turnover } \\
\text { ratio, turnover } \\
\text { per year }\end{array}$ & 3.34 & 4.50 \\
\hline & Debt ratio & 0.27 & 0.51 \\
\hline & $\begin{array}{l}\text { Profitability of } \\
\text { borrowed } \\
\text { capital, } \\
\text { coefficient }\end{array}$ & 0.41 & 0.87 \\
\hline & $\begin{array}{l}\text { Capital } \\
\text { coefficient }\end{array}$ & 0.78 & 0.54 \\
\hline & $\begin{array}{l}\text { Circulating } \\
\text { assets capacity } \\
\text { ratio }\end{array}$ & 0.30 & 0.22 \\
\hline & Capital intensity & 0.54 & 0.83 \\
\hline $\begin{array}{c}\text { General } \\
\text { indicators }\end{array}$ & $\begin{array}{c}\text { Current } \\
\text { (operating) }\end{array}$ & 4.28 & 8.39 \\
\hline
\end{tabular}




\begin{tabular}{|c|c|c|c|}
\hline & $\begin{array}{c}\text { activity, } \\
\text { coefficient }\end{array}$ & 0.11 & 0.45 \\
\cline { 2 - 4 } & $\begin{array}{c}\text { Financial } \\
\text { activity, } \\
\text { Coefficient }\end{array}$ & 0.13 & 0.10 \\
\cline { 2 - 4 } & $\begin{array}{c}\text { Investing } \\
\text { activity, } \\
\text { Coefficient }\end{array}$ & $\mathrm{E}_{\mathrm{ca}}>\mathrm{E}_{\mathrm{fa}}<$ & $\mathrm{E}_{\mathrm{ca}}>\mathrm{E}_{\mathrm{fa}}<$ \\
$\mathrm{E}_{\mathrm{ia}}$
\end{tabular}

The main reason for failing the condition is the inefficiency of the investing activity of the integrated structure of the JSC "Kirov Dairy Plant", which results in income deficiency.

The positive aspect in the integrated structure functioning is that after the integration all parameters, except for the general indicator of the investing activity efficiency, have significantly increased.

Having analyzed the problem, we offer the following management decisions in order to increase the efficiency of functioning of the integrated structure of the JSC "Kirov Dairy Plant" on the basis of the developed algorithm:

- The increase in the size of production and expansion of the product range of milk products as a result of modernizing production facilities,

- The increase in the number of participants of the integrated structure,

- The development of its own distribution system of produced dairy products on regional and interregional markets,

- The formation of customer loyalty by enhancing the brand of manufactured dairy products.

The realization of the proposed managerial decisions will enable the integrated structure of the JSC "Kirov Dairy Plant" to increase the efficiency of its functioning.

\section{Conclusions}

1. Our review of existing approaches to evaluating the efficiency of functioning of the integrated structures has revealed the absence of systematization in the indicators for evaluating their activities according to different groups of parameters.

2. We have offered the methodical approach based on introducing the related general and individual indicators of efficiency of current (operating), financial and investing activities of the integrated structure in industry as one entity.

3. The algorithm for making managerial decisions of the integrated structure has been offered. The essence of this algorithm is choosing actions according to the results of comparing the proposed efficiency indicators of current (operating), financial and investing activities. 4. Due to the practical application of the proposed methodology we have found out the causes of ineffective functioning of the integrated structure of the
JSC "Kirov Dairy Plant". So, a number of recommendations for realizing certain managerial decisions in the field of investing activities have been given.

\section{References}

1. U.N. Androsuk, Economics and Management. Evaluating the performance of the cluster functioning and the sustainable development of the enterprise, 1, 65-70 (2015)

2. A.V. Gordeev, O.A. Maslennikova, S.V. Donskova, N.K. Dolgushin, A.H. Zaveryuha, E.V. Ulyanov, Economics of food industry enterprises (Agrokonsult, Moscow, 2003)

3. T.V. Baibakova, The system for evaluating the financial condition of the integrated unities of dairy of agro-industrial subcomplex in the Kirov region. Monograph (Vyatka state university, Kirov, 2015)

4. L. Kosholkina, N. Borhunov, O.A. Rodionova, AIC: Economy, management. Methodology for determining the parity relations in the agricultural sector, 1, 43-48 (2009)

5. Yu.D. Schmidt, I.M. Romanova, I.S. Mihin, The economic analysis: theory and practice. Complex technique of evaluating the efficiency of the integration processes in bakeries, 30, 13-19 (2009)

6. T.V. Sitnikova, Possibilities of forming the vertically integrated industrial enterprise. http//uecs.ru/uecs54-542013/item/2204-2013-0620-08-16-53

7. S.A. Shubin, Development of the mechanism of forming and evaluating the performance of the vertically-integrated structures (Russian state library, Moscow, 2007)

8. Kin Lo, and Z. Thomas Lys, The Ohlson Model: Contribution to Valuation Theory, Limitations, and Empirical Applications: Sauder School of Business Working Paper (2000).

9. The model of Edwards-Bell-Olson (EBO). http//www.valnet.ru

10. J. Spengler, Journal of political economy. Vertical Integration and Antitrust Policy, 58, 347-352 (1950)

11. O. Willson, New developments in the analysis of market structure. Cambridge (Mass). Vertical Integration and Related Variation on a Transaction-Cost Economics Theme (1986).

12. A.E. Kozhin, Economic efficiency of the vertical integration of timber enterprises (in the example of the Arkhangelsk region) (Russian state library, Moscow, 2003)

13. P.Yu. Poluhin, Evaluating the efficiency of enterprise integration in the sphere of industrial production (Russian state library, Moscow, 2007). 
14. A.A. Popov, The integration of economic entities in the market economy (Russian state library, Moscow, 2005).

15. O.A. Rodionova, N.A. Borhunov, O.A. Grebenkova, Large and small unities: analysis, trends of development and mechanisms of interaction (NIPKTS Voshod-A, Moscow, 2013)

16. M.F. Tazetdinov, Evaluating the economic efficiency of enterprise integration (Russian state library, Kazan, 2006)

17. Yu.V. Yakutin, Russian Economic Journal. Conceptual approaches to evaluating the efficiency of corporate integration, 5, 71-81 (1998)

18. T.V. Baibakova, Economy, labor, management in agriculture. The sectoral approach to evaluating the efficiency of the integrated agrounities, 1, 61-63 (2016)
19. T.V. Baibakova, Economics and Management: problems and solutions. Evaluating the efficiency of the integration processes in the agro-industrial complex, 2(56), 8, 119-123 (2016)

20. L.A. Suvorova, I.V. Pestova, Economics and Management: problems and solutions. The analysis of approaches to evaluating the synergetic effect of functioning of the biotechnology cluster, 2(56), 8, 59-64 (2016)

21. L.A. Suvorova, The synergetic effect of the industry clustering: the analysis, evaluation, forecast. Monograph (the Vyatka State University, Kirov, 2015)

22. L.A. Suvorova, III International Scientific and Practical Conference. Sustainable Development of Society and Economy. Integration, clustering and synergy as the constituent elements of sustainable economic growth 397-398 (2016) 